\title{
Feasibility of Assessing the Developing Human Capital for the Regional Agriculture
}

\author{
Medvedeva Natalia \\ Doctor of Economics, Associate Professor, Vice-Rector for \\ Academic Affairs \\ Federal State Budgetary Educational Institution of Higher \\ Education "Vologda \\ State Dairy Farming Academy Named after \\ N.V. Vereshchagin" \\ Vologda, Russia \\ e-mailnamed35@mail.ru
}

\author{
Agapova Tatiana \\ Doctor of Economics, professor of department of economic \\ security, finances and economic analysis \\ of organization, acronyms acceptable Kikot Moscow \\ University of the Ministry of the Interior of Russia \\ Moscow, Russia \\ e-mail tnagapova@gmail.com
}

\author{
Proka Nina \\ Doctor of Economics, Associate Professor \\ of Department of Economics and Management \\ Federal State Budgetary Educational Institution of Higher Education \\ "Orel State Agrarian University", Orel, Russia \\ e-mail niproka@mail.ru
}

\begin{abstract}
Based on the analysis of the factors, influencing human capital in agricultural industry, this research puts forward the methodological approach to assessing the feasibility of its developmental forecasts. As an example, the article cites the purpose-oriented scenarios of human capital development in the Vologda region, which use various methods and models. The suggested methodology of forecasting enables to promptly detect deviations from given parameters and take informed managerial decisions.
\end{abstract}

Keywords - human capital, agriculture, strategy, scenarios, forecast.

\section{I.INTRODUCTION}

Trends of Russian business growth, related with long-term system challenges in changing international relations and internal barriers, require new approaches to the management of the agricultural sector. According to the Presidential Decree of the Russian Federation №204 on 07.05.2018 «Concerning the national targets and strategic aims of developing the Russian Federation by 2024» the realization of science and technology breakthrough in the agro-industrial complex demands creation of a highly efficient export-oriented sector which development is based on modern technologies and highly-qualified personnel [1]. The 2020 Concept of long-term social and economic development of the Russian Federation defines the major strategic factors, impacting the Russian economic growth, such as increasing global competition, technological progress, human capital [2]. Forecasting, grounded in coordination of aims, tasks and indicators, measuring the achievement of planned criteria both at the state and regional levels, must allow to evaluate not only quantitative characteristics, but also qualitative characteristics of economic entities in agriculture.
Implementation of an accelerated development scenario in agricultural industry, via the intensive use of innovation, raises the value of human assets as a fundamental element of economic growth. Health, knowledge, qualification, living standards of population and leading specialists of organisations, stipulating opportunities for entrepreneurship and innovations in the industry, as has been proved by the experience of countries with well-developed agricultural economy, belong to the number of intensive factors for human capital development that are also paramount for scientific progress and formation of information society.

Nevertheless, the unquestionable importance of human assets for improving the efficiency of agricultural sector has not been resumed so far in the form of a complex developmental plan as part of the documentation on strategic forecasting.

Conclusions drawn from the scientific literature and evaluation of practical activities of economic entities have determined the significance of social and economic forecasts at the regional level, taking into account individual natural and climatic characteristics as well as reflecting the interests and resources of local population.

The necessity to increase the educational and intellectual potential in agriculture represents a reasonably required measure in order to enhance the economic effectiveness of the industry in the long run.

The example forecast of human capital generation in agriculture in the Vologda region is based on the application of economic statistics, spectral analysis, expert assessment and predictive modelling. 
Theory and practice of human capital development, as we see it, is nowadays a systematic generalized summary of economic theories of progress.

The analysis of scientific literature on the topic has resulted in a range of definitions, characterizing the category of «human capital» as a separate unit of economic study. Among the distinguished foreign scientists, working on this topic, there are T. Schultz and S. Becker, who founded theoretical principles of human assets $[3,4]$. Other researchers that further developed studies in this field are S. Fisher, M. Friedman, G. Mintser, G. Kendrick, E. Denison, R. Sollow, S. Kuznets, L. Thurow and etc. $[5,6,7]$. The characteristics of labour market development in agriculture are explored in the works of Lee K. H., Roy. R, Herrendorf B., Inwood S., Dimov D.P., Marvel M.R., Knoop M., Urbancova H. and others $[8,9,10,11]$. Thus, S. Fisher, analyzing the category, states: «Human capital - is a measure of personalized ability to bring profit. Human assets include inborn abilities and talent, as well as education and obtained qualifications» [6]. T. Schultz claims that «human capital» represents the production factor, defining the intensity of innovative progress. Investment in human resources, as T. Schultz believes, enables to improve its professional skills, thus increasing its potential for the state in general [4]. S. Becker researches this category at the organization level, describing it as a combination of human characteristics, including abilities, knowledge and experience [3]. Investing in education, in S. Becker's view, allows enhancing competitiveness of businesses. The essence of human capital theory, according to experts, is that investment in education and healthcare creates human assets, just as financing capital stock contributes to the growth of technical capital [12,13]. Rising intellectual and psychophysical potential assists accelerated return on investment in human resources, improving competitiveness of a system $[14,15]$.

Among Russian researchers who analysed the specific use of this category, E.A. Grishnova is ought to be noted as the one that defines human assets as a combination of human capacity to work, personal qualities, motivation, facilitating the growth of workforce productivity [16]. M.M. Kritskij in his works argues that «human capital is self-enrichment of human life, which is embodied in the quality of life» [17]. The member of Russian Academy of Science L.I. Abalkin, supporting the argument of M.M. Kritskij, puts forward the following definition - «human capital» as «a sum of inborn abilities, general and vocational education, acquired professional experience, creative potential, mental and physical health, motivation factors, securing the possibility to earn income» [5]. I. V. Ilinskii highlights the main constituents of the category: capital of health and capital of culture [18].

The analysis of Russian and foreign scientific works as well as developmental trends of economic entities in agriculture has enabled to determine basic elements of human capital: health, education, motivation.

The summary of specialist literature puts forward two groups of definitions [19]. The first includes a combination of abilities and characteristics of a man, employed in a business process, the second one is focused on investment perspective it concerns the accumulated growth, resulting from financing the development of human resources. We believe that «human capital» as an economic category can hardly be limited to a combined characteristic of health, abilities, knowledge and investment in workforce, it must account for urbanization processes and increasing complexity of labour in the modern type of innovative agricultural economy. The effectiveness of human resources, in our view, depends in many ways on the complex of economic and social factors, determining its suitability to match the needs of public production. In addition, it is important to bear in mind how levels of productive capacity of a man and culture of people correspond with levels of technological advancement in the agricultural industry, as well as given conditions of formation and realization of human capital. The discrepancy between unsuitable characteristics of human assets and manufacturing requirements at the state and regional levels further deepens the structural deformation and hinders the economic growth of the agricultural sector. We think it is feasible to consider the category of «human capital» as accumulation of health, knowledge, skills, experience, communicative and psychophysical potential, involved in production activities, providing income of individuals, as well as benefitting organizations and society in general [20].

The ability to adapt to changing environment, higher qualification, a unique set of skills and talents of a man become the key criterion of system development when innovative breakthrough is under way in the agricultural sector.

Trends of human capital development in the regional agribusiness. The agri-industrial complex of the Vologda region belongs to the prominent and strategically valuable part of its economic sector. Evaluating the economic potential of the regional agricultural industry as an integral part of the European North in the Russian Federation has yielded the objective data for developing long-term scenarios for its economy.

The regional agriculture in the European North of Russia is characterized by higher vulnerability of agricultural business in the area of risky farming which requires considerable financing. Within the studied period the effectiveness of agricultural production in the entities of the European North of Russia tends to decline. The Vologda region specializes in dairy breeding, which is driven by historical traditions and bioclimatic factors, and has the second largest cattle population, and gross milk yield in the North-Western federal region. Producers of agricultural commodities provide the population with food staples (milk, potatoes, eggs) as established by the recommended national nutritional standards.

The analysis of interim results of the state policy in agricultural development and regulating the markets of agricultural products, raw materials and foods in 2013-2020, marks the characteristic growth of major economic indicators, which allows being optimistic about the potential of the regional agribusiness in the long run upon achieving competitiveness [21]. Since 2017 the state programme has included 6 subprogrammes, determining the functioning of the agri-industrial complex and sustainable growth of territories. However, studies of Russian and foreign cases prove that innovative breakthrough in the development of the regional agricultural sector is only possible when accompanied by 
complex development of human potential, and rural areas are not exceptions.

The economic statistics of employing human capital in the region have established the following trends. Since the 90 s of the previous century the demography in the Vologda region has been on decrease.

The number of rural population in the Vologda region declines which coincides the common trend in the country as a whole. The decrease concerns both the proportion of agricultural workers in particular and the rural population in general of the given region.

The process of aging is also rather visible which corresponds with growing rates of non-active age population, and drop in the number of youth which has negative impact of the region economy. However, since 2000 there has been positive change in the birthrate.

The research of migration processes in rural areas shows that the most influencing factors include: the availability of tractors per 100 hectares of arable land, residential housing, healthcare facilities, the gap between incomes in urban and rural households and etc. The migration peaks in prime working years (correlation coefficient - 0,76). Higher degree of wear and tear typical for fixed assets in the agricultural sector decreases labour efficiency which has negative effect on its payment. On the other hand, recently the investment growth in the basic funds has resulted in changing this indicator which now tends to decline (correlation coefficient - 0,86).

The intrinsic factors $x j$, influencing the indicator «total of incoming migrants in rural areas per 1 thousand of population», have been selected as a result of the correlation-regression analysis with the help of inclusion of partial correlation, all limitations and intercorrelation (formula 1).

$Y=-22,69+2,89 \cdot x_{1}-0,672 \cdot x_{2}+0,39 \cdot x_{3}-0,12 \cdot x_{4}$

where $\mathrm{x}_{1}-$ number of tractors per 1000 hectares of arable land, item;

$\mathrm{x}_{2}$ - availability of residential housing, square metres of floor area per resident;

$\mathrm{x}_{3}$ - difference between money income in urban and rural areas per one family member, $\%$;

$\mathrm{x}_{4}$ - number of women per 100 men of active working age.

The factors influencing the indicator «total of departures from rural areas per one thousand of population» have been selected by including the partial correlation, all limitations and intercorrelation (formula 2).

$Y=-1,9+2,39 \cdot x_{1}-0,498 \cdot x_{2}+0,049 \cdot x_{3}-1,11 \cdot x_{4}$

Where $x_{1}-$ number of tractors per 1000 hectares of arable land, item;

$\mathrm{x}_{2}$ - difference between money income in urban and rural areas per one family member, $\%$;

$\mathrm{x}_{3}$ - number of women per 100 men of active working age;

$\mathrm{x}_{4}$ - availability of residential housing, square metres of floor area per resident.
The results of the demography analysis of the region under study demonstrate the negative impact of factors on the quality of human assets in agriculture.

To assess the impact of demographic changes on the production of agricultural commodities in current prices in the Vologda region when using the correlation-regression analysis the following factors are selected: $\mathrm{x} 1$ - index of vital senility; $\mathrm{x} 2$ - special coefficient of male mortality; x3 - special coefficient of female mortality (formula 3 ). The decrease of senility index by $1 \%$ leads to the increase of agricultural production output in the region by $434,5 \mathrm{mln}$. RUB., the drop in male mortality by one results in the growth by $12,38 \mathrm{mln}$. RUB., the decline by $212,2 \mathrm{mln}$. RUB. is caused by rising female mortality.

$$
Y=-236,7+434,48 \cdot x_{1}+12,38 \cdot x_{2}-212,2 \cdot x_{3}
$$

The second model relies on the independent factors to evaluate the influence of demography on agricultural production: $\mathrm{x} 1$ - cumulative birthrate; $\mathrm{x} 2$ - average life expectancy; $\mathrm{x} 3$ - total divorce rate (formula 4 ). The production output goes down at the decreasing birthrate by 121,2 $\mathrm{mln}$. RUB., it climbs up by 49,6 mln. RUB. when the average life expectancy adds 1 year, and increases by 144,02 mln. RUB. at lower divorce rates.

$$
\mathrm{Y}=-1216,1-121,2 \cdot \mathrm{x}_{1}+49,6 \cdot \mathrm{x}_{2}+144,2 \cdot \mathrm{x}_{3}
$$

The established regularities confirm the interdependence and intercorrelation of economic, demographic and social processes in the region.

The use and development of human capital in agricultural business is related with industry characteristics and competitive edge of other industries at job market which has negative influence on the quantity and quality of workforce. Within the studied period the number of agricultural workers decreased 2,4 times. The proportion of retired and preretirement specialists in business is over $45 \%$. The survey among the heads of agriculture businesses in the Vologda region, run within our study in 2017, has revealed considerable demand for experts specializing in "Agronomics", "Animal husbandry", "Agroengineering". Over $80 \%$ of employers regularly lack qualified staff. The most influential factors that impact this process include: lack of experience $(30 \%)$, unattractiveness of agricultural vocation (27\%), no infrastructure and low living standards of rural population $(23 \%)$ and others.

According to the data of Department of Food and Agriculture of the Vologda region the number of offers at the labour market is significantly higher than the total of qualified employees such as veterinarians, agronomists, animal technicians, agricultural engineers, cattle-farm workers, machine milking operators and etc. There is a structural imbalance in the employment market between supply and demand in terms of vocation and qualification. The influx of workforce remains insignificant as agribusiness has lower attractiveness compared to other industries that offer better income and career opportunities.

Development conditions of human capital in agricultural industry. Quick changes in the quality of workforce in agribusiness are hardly feasible which considerably hinders the 
sustainable growth of Russian economy. It seems viable to note that the long-term implementation of the systematic approach to generation of human assets in agribusiness must take into account the following characteristics:

- lack of favourable conditions for human capital development in rural areas;

- limited opportunities for growth due to low living standards and quality of life of rural population;

- higher requirements for quality of human assets;

- deteriorating demography and aging of rural population;

- poor infrastructure in rural areas;

- low motivation of agribusiness to invest in workforce;

- no concerted strategy for interdependent innovative development and agricultural education which has negative effect on the structure and forecasting parameters of the industry recruitment needs in the long run.

All the above mentioned makes it clear that the regional forecasting system of human assets can become the main indicator of the innovative growth of the agricultural sector [22]. The analysis of science and technology development shows that the growth cycle of human capital represents the key element when realizing the innovative breakthrough in agribusiness.

The studies of official strategies, policies and other documentation, regulating development forecasting at the state and regional levels, demonstrate the lack of attention to forecasting and generation of human assets in the agri-industrial complex. Generally, investment in education, healthcare and better infrastructure in rural areas is in the focus.

Predictive scenarios of human capital development. The synergetic forecasting of the long-term development of economic systems causes difficulties when calculating potential trajectories of developmental pathways. At the same time it is hard to argue with G.A. Kotelnikov, who says that «... for a public system, just as in a game of chess, not all the possible moves are actually realized, but only a few of them. Consequently, forecasting of such scenarios and system management require special techniques of continuous selection of options which enable the system to retain or improve its parameters». Within our study the category of «forecasting of human capital» means: the scientific rationale of quantitative and qualitative characteristics of its long-term development. In our view, measurement is more helpful and precise when the essence of the measured substance as well as the reason for measuring it are clear.

The methodology of human capital forecasting in the agricultural industry must allow the compatibility of predictive scenarios both at the state and regional levels. Our long-term outlook includes three development scenarios - conservative, innovative and purpose-oriented which does not contradict the long-term forecast of the social and economic growth of Russia until 2030. (Table 1). The essential prerequisite, in our opinion, defining the generation and development of human assets in agribusiness, is the quality of regional population. Such factors as income of locals, levels of social welfare and consumption, and the like, have the paramount importance as they create conditions not only for physical and mental recovery, but for well-rounded human development.

TABLE 1. PURPOSE-ORIENTED SCENARIO OF HUMAN CAPITAL DEVELOPMENT IN REGIONAL AGRIBUSINESS

\begin{tabular}{|c|c|}
\hline Criteria & Characteristics \\
\hline Labour market & $\begin{array}{l}\text { Drop of economically active population to } 9 \% \text {. Due to } \\
\text { mobility and growth of competence the unemployment } \\
\text { goes down to } 4 \% \text {. Innovative development. Higher } \\
\text { demand for qualified staff. }\end{array}$ \\
\hline Living standards & $\begin{array}{l}\text { Additional financing of priorities. Growth of income } \\
\text { in } 2,5 \text { times, decline of poverty to } 6 \% \text {. Upgrade of } \\
\text { social and engineering infrastructure in rural areas, } \\
\text { higher standards of living of population. Less income } \\
\text { inequality. }\end{array}$ \\
\hline Education & $\begin{array}{l}\text { Increasing expenses on agricultural education by } 30 \% \text {. } \\
\text { Upgrading the contents and technologies of vocational } \\
\text { training to match modern standards of agricultural } \\
\text { production and changing demands of population. }\end{array}$ \\
\hline Healthcare & $\begin{array}{l}\text { Creating the effective healthcare system, competitive } \\
\text { at the European level that provides people with } \\
\text { suitable preventive as well as accessible and good } \\
\text { quality curative care. Growth of expenditure on } \\
\text { healthcare in } 2030 \text { to } 9,4 \% \text { GDP. }\end{array}$ \\
\hline $\begin{array}{c}\text { Culture and mass } \\
\text { media }\end{array}$ & $\begin{array}{l}\text { Providing access to cultural values of Russian and the } \\
\text { world art for population to turn it into a resource of } \\
\text { intellectual and economic development. Increasing } \\
\text { expenses up to } 1,6 \% \text { GDP. Introduction of public- } \\
\text { private partnership. }\end{array}$ \\
\hline $\begin{array}{c}\text { Housebuilding } \\
\text { and housing } \\
\text { market }\end{array}$ & $\begin{array}{l}\text { Financing housebuilding development. Increasing } \\
\text { mortgage proportion up to } 50 \% \text { in } 2030 \text {. Improving } \\
\text { residential housing for rural population. }\end{array}$ \\
\hline $\begin{array}{c}\text { Technologies and } \\
\text { innovation }\end{array}$ & $\begin{array}{l}\text { Innovative breakthrough in agriculture, also with the } \\
\text { help of best accessible technologies. Doubled } \\
\text { production efficiency by } 2030 \text {. Reaching food security. }\end{array}$ \\
\hline
\end{tabular}

Improving these factors will facilitate the growth of level and quality of workforce potential, production efficiency and dynamics of agricultural development as a whole. The upgrade of the agricultural sector will lead to higher demand for qualified staff which requires generating skilled workforce and creating the efficient system of both vocational education and training and retraining of personnel. Increasing professional mobility of human resources enables to attract additional rural workers.

The analysis of existing methods of assessment and forecasting of human assets development concludes that nowadays there is a range of mismatches between information resources, tools, continuous development of human capital, aims and tasks of forecasting when accounting for interdependence with other elements of agriculture as an economic system.

Our study has enabled to draft the system of indicators, allowing forecasting the perspective growth of human assets while taking into account the major strategic criteria of social and economic development of Russia. Establishing the structured system of indicators makes it possible to predict not only the final figures of human capital development in agriculture, but conditions and prerequisites, facilitating its quality increase in the long run. The designed system of 
indicators contains the criteria, included in statistics reports, as well as newer ones, reflecting modern developmental trends of workforce potential. The suggested system enables to account for:

1) various information sources, contributing to complex assessment of quantitative parameters in the development of human assets within the designed forecasts;

2) dynamics of the studied processes, based on macroeconomic indices that are officially published in state forecasts of social economic growth;

3) regularities in changes of investigated indicators, determined by the use of statistical methods;

4) impact of factors, influencing the dynamics of agricultural industry development within the forecast period.

It seems feasible to employ the designed forecasting tools both at the state and regional levels.

We believe that the system of indicators for growth forecasting of human capital in agribusiness must include the following sections:

- key regional characteristics of the area in Russia;

- demographics;

- living standards of population;

- employment and unemployment rates;

- healthcare;

- education;

- leisure and culture;

- residential housing building;

- agriculture;

- technology and innovation.

The designed system of indicators allows to demonstrate the impact of individual elements on the development of human capital, take into account the targets of agricultural production, create the concerted strategy of innovative development of industry and agricultural education (Table 2).

The purpose-oriented scenario for human capital development in regional agribusiness was designed, relying on the data, provided by the regional office of the Federal Service for National Statistics in Vologda, results of statistical and spectral analyses, as well as expert assessment, based on cognitive maps.

The use of comparable prices, together with the data of the Ministry of Economic Development and Trade of the Russian Federation, the principle of Russian Food Security Policy, as well as forecasting criteria of scientific and innovative development, agricultural education in Russia has enabled to ensure the integrity of calculations and its practical importance.
TABLE 2. ForECAST OF HUMAN CAPITAL DEVELOPMENT IN VOLOGDA AGRIBUSINESS: PURPOSE-ORIENTED SCENARIO (EXCERPT)

\begin{tabular}{|c|c|c|c|}
\hline Indicators & 2020 & 2025 & 2030 \\
\hline \multicolumn{4}{|c|}{ demographics } \\
\hline $\begin{array}{ll}\text { Average } & \text { annual } \\
\text { population of } & \text { region, } \\
\text { person } & \end{array}$ & 1191564 & 1174845 & 1152240 \\
\hline $\begin{array}{l}\text { Percentage of rural } \\
\text { population, } \%\end{array}$ & 26,2 & 27,3 & 28,1 \\
\hline $\begin{array}{l}\text { Coefficient } \\
\text { migration turnover in } \\
\text { rural areas, per mil }\end{array}$ & 95 & 100 & 104 \\
\hline \multicolumn{4}{|c|}{ living standards } \\
\hline $\begin{array}{l}\text { Average income (per } \\
\text { month), RUB. }\end{array}$ & 29430 & 35786 & 52781 \\
\hline $\begin{array}{ll}\text { Real income } & \text { as } \\
\text { percentage \% as } \\
\text { previous years }\end{array}$ & 96,3 & 100 & 108,3 \\
\hline $\begin{array}{l}\text { Average gross payroll } \\
\text { in agribusiness, RUB. }\end{array}$ & 32442 & 41223 & 57876 \\
\hline \multicolumn{4}{|c|}{ education } \\
\hline $\begin{array}{l}\text { Average state } \\
\text { examination grade of } \\
\text { students enrolled in } \\
\text { agricultural } \\
\text { universities, point }\end{array}$ & 61 & 63 & 68 \\
\hline $\begin{array}{l}\text { Number } \\
\text { consultancies in } \\
\text { region, item }\end{array}$ & 5 & 8 & 10 \\
\hline $\begin{array}{l}\text { Percentage of retrained } \\
\text { employees } \\
\text { agribusinesses, \% }\end{array}$ & 50 & 65 & 75 \\
\hline \multicolumn{4}{|c|}{ agriculture } \\
\hline $\begin{array}{l}\text { Agriculture products in } \\
\text { real prices, mln. RUB. }\end{array}$ & 46896 & 72998 & 98712 \\
\hline $\begin{array}{l}\text { Indices of agricultural } \\
\text { production in } \\
\text { comparable prices in } \% \\
\text { as of previous year }\end{array}$ & 106 & 109 & 115 \\
\hline $\begin{array}{l}\text { Milk production per } \\
\text { cow, kg }\end{array}$ & 6116,2 & 7460,1 & 8212,3 \\
\hline \multicolumn{4}{|c|}{ technology and innovation } \\
\hline $\begin{array}{l}\text { Expenses on } \\
\text { technology innovation } \\
\text { in agribusiness, RUB in } \\
\text { thousands. }\end{array}$ & 5075 & 7210 & 9870 \\
\hline $\begin{array}{l}\text { Percentage of } \\
\text { agricultural production, } \\
\text { made with the help of } \\
\text { innovation, \% }\end{array}$ & 30 & 58 & 70 \\
\hline
\end{tabular}

\section{II.CONCLUSION.}

The methodology, employed for writing forecasting scenarios for the period until 2030, enables to include:

- the parameters of statistical regularities in changes of human capital in the long run;

- forecasting the values of changing macroeconomic indices, as well as the predictive scenarios of social and economic development of Russia;

- the criteria and strategic priorities of the state programme «Agricultural development and regulating the markets of agricultural products, raw materials and foods in 2013-2020».

This research accounts for correlations in conditions of emerging systems in vocational education, science, healthcare, different in terms of its impact on long-term development conditions for generating human assets in agribusiness. The purpose-oriented scenario is realized via improvements in the mechanisms of state support, development of scientific and educational potential, training qualified staff, capable to 
implement innovative projects to match advanced requirements in the agricultural industry.

\section{References}

[1] "Comcerning national targets and strategic aims of development of the Russian Federation until 2024", Presidential Decree of the Russian Federation № 204 on 07 May 2018, Retrieved from: http: http://www.garant.ru/hotlaw/federal/1195467.

[2] "Long term forecast of social development of the Russian Federation for the period until 2030”, Government Decree № 1297 since 26 March 2013 , Retrieved from: http:// http://www.garant.ru/news/464503.

[3] S. Becker, T. Whisler,. "The innovative organization: A selective view of current theory and research", Journal of Business, 1967, vol.. 40, pp. 462469

[4] T. Schultz,. "Investment in Human Capital: The Role of Education of of Research", New York: Free Press Publishing, 1970, p. 272.

[5] L.I. Abalkin, "The Strategy of Russia in Response to Challenges of New Century", ed. L.I. Abalkin, Moscow: Publishing House «Ekzamen», 2004, p. 608.

[6] S Fisher, Dornbush, R. Shmalenzi, "Economic theory", Moscow: Unity, 2002, p.864 p.

[7] K. Lee, D. Manuer, E. Xu, "Human capital relatedness and mergers and acquisitions", Journal of financial economics, 2018, vol. 129, no. 1. pp. 111-135. DOI: 10.1016/j.jfineco.2018.03.008

[8] R. Roy, S. Shijin, "Dissecting anomalies and dynamic human capital: The global evidence", Borsa Istanbul review, 2018, vol. 18, no. 1. pp. 1-32, DOI: 10.1016/j.bir.2017.08.005

[9] B. Herrendorf, T. Schoellman, "Wages, Human Capital, and Barriers to Structural Transformation", American economic journalmacroeconomics, 2018, vol. 10 , no. 2, pp. 1-23, DOI: $10.1257 / \mathrm{mac} .20160236$

[10] S. Inwood, "Agriculture, health insurance, human capital and economic development at the rural-urban-interface". Journal of rural studies, 2017, vol. 54, pp. 1-14.,DOI: 10.1016/jirurstud.2017.05.009.
[11] D. Dimon, D. Shepherd, "Human capital theory and venture firms: Exploring «home rums» and «strike outs»", Journal of Business Venturing, 2005, vol. 20, no. 1. pp. 1-21

[12] M. Marvel, "Human capital and search-based discovery: A study of high entrepreneurship", Theory and Practice, 2013, vol. 37, no. 2. pp. 403-419.

[13] M. Knoop, "Human resources management illustrated with special crops as an example", Berichte uber Landwirtschaft, 2018, vol. 96, no. 2, pp. 121.

[14] H. Urbancova, R. Richter, L. Kucirkova, M. Jarkovska, "Employer branding in the agricultural sector: Making a company attractive for the potential employees", Agricultural Economics, 2017, vol. 63, no. 5, pp. 217-227

[15] T. Hlavsa, H. Urbancova, R. Richter, "Ways of human resource branding in Czech agricultural companies", Scientia Agriculturae Bohemica, 2015, vol. 46, no. 3. pp. 112-120.

[16] E.A. Grishnova, "Human Capital: generation in the system of education and training", Kiev: Znaniya, 2001, p. 254

[17] M.M. Kritskij, "Human Capital", Leningrad: Publishing House of LSU, 1991, p. 120.

[18] I.V. Ilinskii, "Investment in Future: education in innovative production", Saint Petersburg : SPbUEF, 1996, p. 163.

[19] T.N. Agapova, N.A. Medvedeva, "Human Capital - factor of innovative development of regional agriculture", Bulletin of Volga Region State University of Service. Series «Economy», 2014, № 4(36), pp. 43-48.

[20] T.N. Agapova, N.A. Medvedeva, "Structural changes in the agricultural sector of Volga region economy", Bulletin of Volga Region State University of Service. Series «Economy», 2010. № 5(13), pp. 73-78.

[21] B. N. Kuzyk, Yu.V. Iakovets, Russia- 2050: strategy of innovative breakthrough Moscow: Publishing House «Economy», 2005, p. 624.

[22] G.A. Kotelnikov, "Issues of institutionalisation of social and synergetic approach to developing social technologies", Technologies of social management : proceedings of international applied research conference. Part 1, Moscow Belgorod, 1995, pp. 68-70 